Schulich School of Law, Dalhousie University

Schulich Law Scholars

Articles, Book Chapters, \& Blogs

Faculty Scholarship

$7-1-2020$

The Political Economy of Nigeria's Digital Tax Experiment

Okanga Ogbu Okanga

Follow this and additional works at: https://digitalcommons.schulichlaw.dal.ca/scholarly_works

Part of the Human Rights Law Commons, and the Tax Law Commons 


\section{The Political Economy of Nigeria's Digital Tax Experiment}

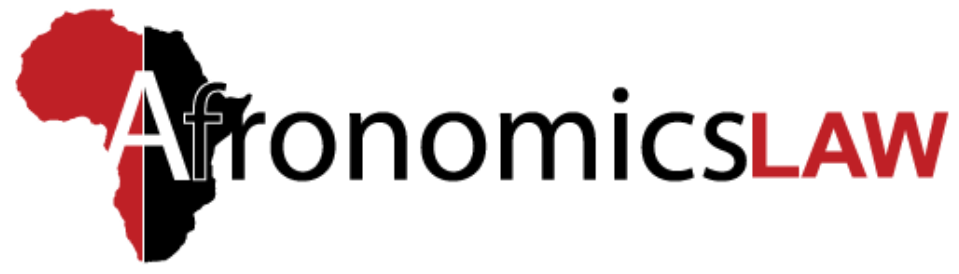

Category:

Analysis

Subcategory:

Stand-Alone Posts

By:

\section{Okanga Og $\underline{\text { bu Okanga }}$}

July 1,2020

In January 2020 when I first read Nigeria's Finance Act 2019, one of the instinctive questions that came to me was "is Nigeria serious about taxing digital trade now"? There were a few reasons for this skepticism. First, the Act seeks to tax nonresident companies (NRCs) that have a "significant economic presence" (SEP) in Nigeria but then delegates the definition of that pivotal phrase. Second, I questioned how Nigeria can enforce/administer this unilateral tax, which is payable by companies outside its borders. Third, I imagined that Nigeria's unilateral attempt to tax digital trade could undermine relations with a strategic economic, and political partner, the US. Nigeria has now crossed the first hurdle of defining SEP - no doubt, a meaningful step forward - yet, there remains much to process before Africa's biggest economy can begin to milk the digital cow.

Nigeria is in the middle of extensive tax reform. Shortfalls in revenue, underscored by the country's ultra-low tax-to-GDP ratio and humongous debt profile, as well as a longstanding need to diversify the economy from petroleum exports, are some of the drivers of reform. One of the most pronounced reforms introduced by the Finance Act borders on the taxation of digital trade. Section 4 of the Finance Act amends the Companies Income Tax Act (CITA) by introducing a new paragraph 13(2)(c). By that new provision, an NRC is liable to tax in Nigeria if it conducts business in Nigeria through electronic means (such as the transmission of sounds, signals, images, data) to the extent that the company has an SEP in Nigeria and profit can be attributed to the NRC's activities in Nigeria. The businesses contemplated include ecommerce, streaming/downloading services, data collection/transmission service, cab hire services, and advertising. 
Further, the Finance Act introduces a new paragraph 13(2)(e) of CITA, by which nonresident technical, management, consultancy or professional services are liable to tax in Nigeria if they serve a Nigerian resident, to the extent that the service provider has an SEP in Nigeria.

The recently issued Companies Income Tax (Significant Economic Presence) Order 2020 now provides the missing definition. As part of the definition, an NRC is deemed to have an SEP in Nigeria if its digital trade activities earn a turnover or income of $\$ 25,000,000$ $(\$ 65,000)$. The Order anticipates that localized advertising and use of domain name will also qualify as SEP, without any revenue threshold. There is also no revenue threshold for paragraph 13(2)(e) of CITA. These measures are designed to operate pending the conclusion of ongoing multilateral deliberations on the formulation of digital tax rules.

The new CITA rules try to adapt Nigeria's tax framework to the reality of modern business, which is that so much is done and earned digitally and remotely nowadays; i.e. without the need for a physical presence in the country where income is derived. The new rules also have significant implications for both international tax and international trade relations. Taxing NRCs without a physical nexus represents a fundamental shift from subsisting international tax rules/conventions on allocation of taxing powers between states. The current rules, which are under review, typically require the existence of a physical presence in the taxing country, usually termed a "permanent establishment" (PE), for the taxation of the business profits of an NRC. So, in context, unilateral measures, such as Nigeria's (which try to bypass the traditional PE rule), while assertive of a state's sovereignty, may, regardless, contravene international convention or even legally binding pacts, where there is a double taxation treaty (DTT).

There is broad opinion that the existing international rules - designed a century ago - are no longer fit for purpose. These opinions target the unfair distribution of taxing rights among states as well as the present digital trade/tax conundrum. Many agree that there is need to adjust the subsisting rules in the light of radical digitalization that has, in many cases, created room for the misalignment of value creation with tax obligation. One of the tax consequence of the present situation, for Nigeria, is that multinational NRCs typically avoid operational or investment structures that result in the creation of a PE in Nigeria when they are providing digital goods or services. The OECD/G20 Inclusive Framework on BEPS leads the multilateral efforts to adjust the rules. Nigeria is a participant. International tax rules are typically the product of political bargain (such as the OECD is trying to strike) but when bargaining struggles or fails to produce the required consensus, there is a risk of pervasive unilateralism. It is no surprise, therefore, that, in the face of protracted OECD deliberations, further hampered by the COVID-19 pandemic, Nigeria is just one of many countriesseeking to tax nonresident digital businesses. The US, the home state of many of the most powerful players in the digital trade space - Amazon, Apple, Google, Microsoft, Facebook, etc. sternly opposes any such unilateral tax measures, while approaching multilateral efforts with some degree of resentment. The US asserts exclusive sovereignty to tax its digital companies, regardless of where they profit, and has severally expressed willingness to go to 
trade war with any country, including some of its closest allies (the UK and France, for instance), over the issue. The US only recently pulled out of the OECD-led talks citing an impasse in reaching a deal.

\section{US-Nigeria relations}

Unlike countries such as the UK and France, Nigeria does not have a DTT with the US, so, technically, there are no legal constraints on Nigeria applying an expanded definition of "taxable presence" in its tax code in a way that taxes U.S. corporations digitally operating in Nigeria. There are, however, ecopolitical factors that make it incumbent on Nigeria to thread with caution, and, perhaps, await a multilateral solution.

The US is a close and critical ally of Nigeria's and one of the largest foreign investors in the African country. The world's most powerful economy has reemerged as a big buyer of Nigeria's oil, an export that is critical to Nigeria's survival. Apart from trade, the US provides Nigeria both military and non-military aid. In addition, Nigerians living in the US remit billions of dollars yearly in much needed cash. In seeking to enforce the new rules, Nigeria risks impacting its relationship with a much more powerful counterpart. There are palpable signs that the US is not shy to redress its relations with Nigeria if it feels dissatisfied. During the Jonathan-Obama era, the U.S. imposed a "Leahy Law" arms sale restriction on Nigeria for

gross human rights violations allegedly committed by Nigeria's armed forces in the war against Boko Haram. Relations were again briefly strained in January 2020, resulting in the US imposing a visa ban on Nigeria. Standing beside his Nigerian counterpart, US Secretary of State, Mike Pompeo, made sure to stress US investment in Nigeria and the two countries' strategic economic, political and military relations when addressing the visa issue. It is, perhaps, merely coincidental that this strain escalated just after President Buhari signed the Finance Act. So far, only the powerful EU bloc - or some members of that bloc - has shown any resolve to enter the ring with the U.S. over this issue. It is hard to think that Nigeria would assert itself that far given its relatively much weaker capacity to stomach and respond to a US reprisal. A potential US backlash against Nigeria is not so much anchored on the prospect that the Nigerian tax will significantly hurt the bottomline of US companies, but rather that the US simply does not want anyone to think "we can do this." The deterrent approach reflects the point that "if the U.S. 'lets' Nigeria do it, why not others"?

\section{Why now for Nigeria?}

It seems that Nigeria is even more fiscally strained than it was in early 2020 when the Finance Act was signed. Since then, the COVID-19 pandemic has ravaged the country's revenue projections, with oil markets in disarray. Recently, Nigeria's President requested approval from the National Assembly to borrow an additional $\$ 5.5$ Billion. This is on the heels of another request, in April, to borrow the sum of \$2.36 Billion. At the same time, Nigeria is passionately pleading with some international creditors to cancel some of the country's foreign debts, to help cushion the economic effects of the pandemic. 
In a rather bizarre twist, in April, the Federal Inland Revenue Service (FIRS) issued a circular pleading with certain corporate bodies - Telcos, e-Commerce, Financial Institutions, etc. that were "experiencing boom" as a result of the pandemic to redeem their tax obligations ahead of time. On 29 April 2020, the FIRS released a circular outlining the intention of the government to commence implementation of provisions of the Stamp Duties Act that impose stamp duty on electronic documents. The dutiable instruments or receipts mentioned in the circular include electronic documents or files, emails, short message service, instant messages, any internet-based messaging service, website, or cloud-based platform. With such a vigorously displayed need for cash, it is easy to see why Nigeria is eager to tax digital transactions. Moreover, by official projections, there are indications that investments in the digital economy will generate up to $\$ 88$ Billion and three million jobs for Nigerians before the end of 2021.

\section{Conclusion}

The principle of administrability requires that a state imposes only a tax that it can administer and collect. While any country can draft whatever it likes into its tax code, it is important that a country only drafts what it can administer/enforce. By the language of the Finance Act, the taxpaying NRC must have a "significant economic presence" in Nigeria and profits must be attributable to that the company's Nigerian activities. Legally speaking, Nigeria can only tax where these criteria exist. Without bilateral or multilateral cooperation, it will be impracticable for Nigeria to administer its digital tax law. Nigeria may need the aid of its counterparts financial institutions, as well - to track and collect the taxes. Although there are existing cooperation and exchange of information agreements, it is arguable that those agreements do not capture the tax regime that Nigeria is trying to impose. Thus, other countries may not be obligated to disclose information on their corporations operating digitally in Nigeria. Without information, it is difficult to tell what an NRC's turnover is, not to mention how much of that turnover qualifies as profit attributable to Nigeria, unless the FIRS invokes the deemed profit option in section 30(1) of CITA.

Even where information is available, without mutual collection agreements with other countries, Nigeria can still not collect. This may lead to a disruptive/non-neutral situation where Nigeria is only able to enforce the law against companies that are voluntarily cooperative or resident in cooperative countries. Imagine, just hypothetically, the anticompetitive effect on streaming services of taxing Spotify (a Swedish enterprise) and Deezer (a French enterprise) but not Apple or YouTube Music (American enterprises). If Nigeria uses a deduction at source model, it is unlikely to capture enough of the tax base to warrant the trouble, since most transactions contemplated are business-to-customer-based.

An alternative would be to work with the payment outlets to automate charges on businessto-customer transactions and, perhaps, business-to-business transactions. Even then, the NRCs may simply pass on the tax burden to their (aggrieved) Nigerian consumers, making it look more like a consumption tax rather than a tax on income. It all seems like a lot of effort. Yet, in that assertive endeavour, Nigeria risks straining some vital external relations that 
could have repercussions for the country in both economic and political respects. It is possible that the fallout could even have more impact on Nigeria's fiscal bottomline than the revenue that Nigeria stands to raise from implementing the now incubating tax measure. These staring practical and policy-based considerations drive me back to my new year question: "is Nigeria serious about taxing digital trade now"?

Login or register to post comments 